\section{Foliar SPAD-502 Meter Values, Nitrogen Levels, and Extractable Chlorophyll for Red Maple Selections}

\author{
Jeff L. Sibley ${ }^{1}$, D. Joseph Eakes ${ }^{2}$, Charles H. Gilliam³ ${ }^{3}$, Gary J. Keever ${ }^{3}$, \\ William A. Dozier, Jr. ${ }^{3}$, and David G. Himelrick ${ }^{3}$ \\ Department of Horticulture, Auburn University, AL 36849
}

Additional index words. Acer rubrum, Acer $\times$ freemanii, leaf greenness, summer color, foliage characteristics

\begin{abstract}
Twelve red maple selections in an existing field trial were evaluated for leaf chlorophyll content with a SPAD-502 chlorophyll meter, total foliar $N$ concentration with a LECO CHN analyzer, and total foliar chlorophyll content (CHL) by $N, N$ dimethylformamide extraction. Selections included Acer rubrum L. 'Autumn Flame', 'Fairview Flame', 'Franksred' (Red Sunset ${ }^{\mathrm{TM}}$ ), 'Karpick', 'Northwood', 'October Glory', 'Redskin', 'Schlesingeri', and 'Tilford', and A. Xfreemanii E. Murray 'AutumnBlaze' ('Jeffersred'), 'Morgan' ('Indian Summer'), and 'Scarsen' (Scarlet Sentinel' ${ }^{\mathrm{TM}}$ ). 'Franksred' and 'Northwood' had the highest monthly SPAD-502 values in 1993 and 1994. Lowest SPAD-502 values were on 'Redskin' and 'Autumn Blaze' each year. Foliar N concentration ranged from $2.62 \%$ for 'Autumn Flame' to $2.01 \%$ for Redskin. CHL levels on a freshweight basis ranged from $5.38 \mathrm{mg} . \mathrm{g}^{-1}$ for 'Fairview Flame' to $3.94 \mathrm{mg} \cdot \mathrm{g}^{-1}$ for 'October Glory'. SPAD-502 and extractable CHL values were correlated $(r=0.45 ; P \leq 0.001)$; however, the correlation $(r=0.15 ; P \leq 0.38)$ between SPAD-502 values and total foliar $N$ concentration was nonsignificant.
\end{abstract}

Red maples are among the most frequently occurring trees in municipalities and landscapes across the United States (Kielbaso, 1990). Numerous red maple cultivars are readily available (Dirr, 1990; Santamour and McArdle, 1982; van Gelderen et al., 1994). The popularity of cultivars rests on their uniformity with regard to form, foliage characteristics, or fall color. In recent years, cultivars also have been developed from crosses and backcrosses between red maple and silver maple (Acer saccharinum L.). These selections are recognized botanically as Acer $\times$ freemanii E. Murray (Freeman maple) (Bachtell, 1988). Current literature lacks documentation on differences in foliage characteristics used to distinguish cultivars. Although isozyme analyses (Tobolski and Kemery, 1992) and DNA amplifications (Krahl et al., 1993) are reliable methods for establishing cultivar identities, these methods are complicated, largely unavailable, or too expensive for a rapid cultivar identification and not suited for use in the field.

Received for publication 22 May 1995. Accepted for publication 12 Jan. 1996. Mention of a trademark or proprietary product does not imply endorsement of the products named or criticism of other products not named that may also be suitable. The cost of publishing this paper was defrayed in part by the payment of page charges. Under postal regulations, this paper therefore must be hereby marked advertisement solely to indicate this fact.

${ }^{1}$ Graduate Research Assistant.

${ }^{2}$ Associate Professor.

${ }^{3}$ Professor.
Use of chlorophyll meters to assess levels of chlorophyll or leaf greenness are now widely accepted (Himelrick et al., 1992; Kaakeh et al., 1992; Marquard and Tipton, 1987; Savé et al., 1995). Chlorophyll meter readings have been correlated to total extractable chlorophyll (CHL) in various crops (Kaakeh et al., 1992; Marquard and Tipton, 1987; Monje and Bugbee, 1992; Savé et al., 1995; Yadava, 502 chlorophyll meter (Minolta Camera Co., Japan) in horticulture continues to expand. Tenga et al. (1989) were able to use a chlorophyll meter to assess ozone injury to tomato leaves (Lycopersicon esculentum Mill.). Fanizza et al. (1991) linked leaf greenness measurements to water stress in genotypes of grapes (Vitis vinifera L.). Also, use of the SPAD-502 chlorophyll meter has proven effective in determining the $\mathrm{N}$ status of various crops (Himelrick et al., 1993; Turner and Jund, 1991; Wood et al., 1993).

Limited delineation among red maple cultivars regarding summer leaf color has been reported (Fare, 1989; Johnson, 1993; Williams et al., 1993). Our study was initiated to objectively evaluate selected red maples under similar growing conditions by characterizing the development and stability of summer foliage color using a SPAD-502 chlorophyll meter and to compare values based on it to extractable CHL levels. To our knowledge, efforts to correlate the foliar $\mathrm{N}$ status of red maple to SPAD-502 chlorophyll meters have not been reported. Our study evaluated the relationship between SPAD-502 values and foliar $\mathrm{N}$ as determined by combustion with a LECO CHN-600 analyzer (LECO Corp., St. Joseph, Mich.). Total $\mathrm{N}$ recovery has been closer to the true values with this analyzer than 1986). The range of application of the SPAD- with the standard Kjeldahl procedure (Himelrick et al., 1993).

\section{Materials and Methods}

The cultivars included in these trials represent a broad range of available red maple cultivars with regard to introduction date, morphology, and other characteristics (Dirr, 1990). Plant selections were obtained in Mar. 1988 as microplantlets from a single nursery source (Microplant, Fairview, Ore.). Selections included nine Acer rubrum accessions ['Autumn Flame', 'Fairview Flame', 'Franksred' (Red Sunset ${ }^{\mathrm{TM}}$ ), 'Karpick', 'Northwood', 'October Glory', 'Redskin', 'Schlesingeri', and 'Tilford'] and three $A$. $\times$ freemanii genotypes ['Autumn Blaze' ('Jeffersred'), 'Morgan' ('Indian Summer'), and 'Scarsen' (Scarlet Sentinel ${ }^{\mathrm{TM}}$ )].

Trees were set in 2.8-liter containers (\#1 nursery pots) in a 6 pinebark : 1 sand medium $(\mathrm{v} / \mathrm{v})$ amended with $\left(\mathrm{kg} \cdot \mathrm{m}^{-3}\right) 8.3$ Sierrablen (O.M. Scott Co., Maryville, Ohio), 0.9 Micromax (O.M. Scott Co.), and 3.0 dolomitic limestone. Trees were grown in a doublelayer, polyethylene-covered greenhouse for 3 months, then outside under overhead irrigation for the remainder of the growing season. Trees were transplanted in 1989 to 9.5-liter containers (\#3 nursery pots). One year later, trees ranging in height from 1.2 to $1.5 \mathrm{~m}$ were transplanted (Mar. 1990) into a Cecil gravelly sandy loam soil at the Piedmont Substation, CampHill, Ala. (lat. $32^{\circ} 83^{\prime} \mathrm{N}$, long. $85^{\circ} 65^{\prime} \mathrm{W}$ ). A randomized complete-block design was used with five replications of two plants each and a spacing of $9.1 \times 10.7 \mathrm{~m}$. Trees were fertilized at planting and annually in March before budbreak with $0.21 \mathrm{~kg}$ of $13 \mathrm{~N}-5.6 \mathrm{P}-10.8 \mathrm{~K}$ (13-13-13) per centimeter of trunk diameter measured $30.5 \mathrm{~cm}$ above ground level. Soil $\mathrm{pH}$ was sampled annually and maintained at $\mathrm{pH}$ 5.8 to 6.2. Drip irrigation was supplied to each tree, based on $100 \%$ replacement of net evaporation from a class A pan.

Leaf chlorophyll levels were quantified nondestructively with the same SPAD-502 chlorophyll meter monthly from May to Sept. 1993 and 1994. Measurements were taken at midcanopy, on single, healthy, fully expanded leaves, four to five nodes from branch apex. Triplicate readings were recorded and averaged per tree and per replication (30 measurements/cultivar/month).

Extraction of chlorophyll (CHL) from fresh foliage followed methods outlined by Inskeep and Bloom (1985) using $N, N$-dimethylformamide (DMF). Six fresh leaves were collected randomly in June 1993, four to five nodes from the branch apex from all trees per cultivar and transported to a laboratory in Auburn for analyses. SPAD measurements were taken within five circles drawn on the back of each leaf and averaged per leaf $(n=$ $300)$. A paper hole punch $\left(0.31 \mathrm{~cm}^{2}\right)$ was used to remove leaf disks within these circles. The disks were weighed and placed in sealed test tubes containing $5 \mathrm{ml}$ DMF. The tubes were placed in a revolving rack at $4 \mathrm{C}$, in darkness, for $24 \mathrm{~h}$ before $\mathrm{CHL}$ extraction. Extracts were 
assayed with a double-beam spectrophotometer (model 25; Beckman Instruments, Irvine, Calif.) for differences in attenuances at 647 and $664.5 \mathrm{~nm}$ (Inskeep and Bloom, 1985).

Foliar N levels were determined with a LECO CHN-600 analyzer on 25 disks removed with a paper hole punch $\left(0.31 \mathrm{~cm}^{2}\right.$ per disk) from six leaves ( 150 disks/tree) of the 12 selections collected randomly, four to five nodes from the branch apex in Aug. 1993. Nitrogen determinations were repeated in September using three leaves per cultivar. Disks were oven-dried (80C) and ground in a cyclone mill and passed through a $0.5-\mathrm{mm}$ sieve. Total dry weight of each sample was taken and analyzed by combustion for N. For comparison purposes, $\mathrm{N}$ levels also were determined in Sept. 1994 using a modified micro-Kjeldahl procedure using a selenium catalyst (Baker and Thompson, 1992).

Each disk used for $\mathrm{N}$ determinations was measured for CHL content by a SPAD-502 chlorophyll meter immediately after excision with the hole punch and averaged for each tree.

Data were analyzed by analysis of variance using a general linear model procedure (PROC GLM, SAS version 6.04) and correlation procedure (PROC CORR, SAS version 6.04). Differences among cultivar means were determined by DMR test at $P \leq 0.05$ for each evaluation. Annual differences by cultivar were analyzed using a two-sample $t$ test (PROC TTEST, SAS version 6.04).

\section{Results and Discussion}

Measured SPAD-502 chlorophyll meter values confirmed previous subjective evaluations of foliage greenness in red maple cultivars (Fare et al., 1989; Williams et al., 1993). In 1993, 'Franksred' and 'Northwood' had the highest average SPAD-502 values over a 5month season (Table 1). These results were similar to the seasonal chlorophyll peaks and progression of 'Franksred', 'Northwood', and 'Autumn Flame' reported by Johnson (1993). 'Schlesingeri' has late-emerging foliage in Alabama and, as a result, had poorly developed color in May but deep-green foliage in September. Chlorophyll levels in all cultivars increased $(r=0.91 ; P \leq 0.0001)$ over the course of the 1993 growing season, with the exceptions of 'Morgan' and 'Scarsen'.

In 1994, 'Northwood' again showed the highest seasonal average SPAD-502 value, followed by 'Franksred', 'Schlesingeri', and 'Autumn Flame' (Table 2). The chlorophyll index generally increased for all cultivars from May through July 1994, but decreased in August and September. 'Autumn Flame', 'Fairview Flame', 'Morgan', and 'Northwood' each had higher SPAD-502 seasonal averages in 1994 than 1993 with no differences in the seasonal averages for other cultivars $(P \leq$ $0.05)$.

Determinations of leaf CHL content by extraction proved to be laborious, slow, and costly. Total CHL levels on a fresh-weight basis ranged from $5.38 \mathrm{mg} \cdot \mathrm{g}^{-1}$ for 'Fairview Flame' to $3.94 \mathrm{mg} \cdot \mathrm{g}^{-1}$ for 'October Glory'. There was a positive correlation between ex-

Table 1. Chlorophyll index using a SPAD-502 chlorophyll meter for select red maple cultivars and a seedling group, 1993.

\begin{tabular}{lcccccc}
\hline & Season & \multicolumn{5}{c}{ Monthly SPAD-502 values } \\
\cline { 3 - 7 } Cultivar/seedling & avg & May & June & July & August & September \\
\hline Autumn Blaze & $39.2^{\mathrm{z}} \mathrm{h}^{\mathrm{y}}$ & $36.9 \mathrm{de}$ & $37.0 \mathrm{f}$ & $37.4 \mathrm{~h}$ & $41.5 \mathrm{de}$ & $43.0 \mathrm{~d}-\mathrm{f}$ \\
Autumn Flame & $42.7 \mathrm{de}$ & $38.4 \mathrm{~cd}$ & $41.6 \mathrm{~d}$ & $42.8 \mathrm{~b}-\mathrm{d}$ & $45.4 \mathrm{c}$ & $45.2 \mathrm{~cd}$ \\
Fairview Flame & $43.5 \mathrm{~cd}$ & $38.9 \mathrm{c}$ & $43.6 \mathrm{c}$ & $42.5 \mathrm{c}-\mathrm{e}$ & $45.4 \mathrm{c}$ & $47.0 \mathrm{bc}$ \\
Franksred & $50.6 \mathrm{a}$ & $47.2 \mathrm{a}$ & $50.9 \mathrm{a}$ & $49.3 \mathrm{a}$ & $53.4 \mathrm{a}$ & $52.2 \mathrm{a}$ \\
Karpick & $43.8 \mathrm{c}$ & $37.2 \mathrm{c}-\mathrm{e}$ & $42.7 \mathrm{~cd}$ & $44.2 \mathrm{bc}$ & $47.1 \mathrm{c}$ & $47.7 \mathrm{~b}$ \\
Morgan & $42.3 \mathrm{ef}$ & $42.0 \mathrm{~b}$ & $43.8 \mathrm{c}$ & $41.9 \mathrm{~d}-\mathrm{f}$ & $43.1 \mathrm{~d}$ & $40.6 \mathrm{f}$ \\
Northwood & $50.0 \mathrm{a}$ & $48.0 \mathrm{a}$ & $51.6 \mathrm{a}$ & $49.1 \mathrm{a}$ & $50.8 \mathrm{~b}$ & $50.3 \mathrm{a}$ \\
October Glory & $40.3 \mathrm{~g}$ & $35.9 \mathrm{e}$ & $39.3 \mathrm{e}$ & $39.7 \mathrm{fg}$ & $42.1 \mathrm{de}$ & $44.2 \mathrm{~d}$ \\
Redskin & $39.2 \mathrm{~h}$ & $35.3 \mathrm{e}$ & $39.4 \mathrm{e}$ & $39.3 \mathrm{gh}$ & $40.3 \mathrm{e}$ & $41.4 \mathrm{ef}$ \\
Scarsen & $42.6 \mathrm{e}$ & $43.3 \mathrm{~b}$ & $43.0 \mathrm{~cd}$ & $40.5 \mathrm{e}-\mathrm{g}$ & $42.7 \mathrm{~d}$ & $43.6 \mathrm{de}$ \\
Schlesingeri & $45.6 \mathrm{~b}$ & $37.1 \mathrm{c}-\mathrm{e}$ & $45.7 \mathrm{~b}$ & $44.9 \mathrm{~b}$ & $49.3 \mathrm{~b}$ & $50.9 \mathrm{a}$ \\
Tilford & $41.5 \mathrm{f}$ & $38.4 \mathrm{~cd}$ & $43.3 \mathrm{~cd}$ & $41.3 \mathrm{~d}-\mathrm{g}$ & $43.2 \mathrm{~d}$ & $41.5 \mathrm{ef}$ \\
\hline
\end{tabular}

${ }^{2}$ Units for SPAD-502 chlorophyll meter are dimensionless values, not percentages.

${ }^{y}$ Mean separation within columns by Duncan's multiple range test, $P \leq 0.05$.

Table 2. Chlorophyll index using a SPAD-502 chlorophyll meter for select red maple cultivars and a seedling group, 1994.

\begin{tabular}{lcccccc}
\hline & Season & \multicolumn{5}{c}{ Monthly SPAD-502 values } \\
\cline { 3 - 6 } Cultivar/seedling & avg & May & June & July & August & September \\
\hline Autumn Blaze & $40.1^{\mathrm{z}} \mathrm{i}^{\mathrm{y}}$ & $38.3 \mathrm{f}$ & $40.4 \mathrm{f}$ & $41.1 \mathrm{e}$ & $40.8 \mathrm{~d}$ & $40.1 \mathrm{c}-\mathrm{e}$ \\
Autumn Flame & $46.1 \mathrm{c}$ & $42.3 \mathrm{de}$ & $46.0 \mathrm{bc}$ & $47.9 \mathrm{~b}$ & $47.0 \mathrm{~b}$ & $48.3 \mathrm{a}$ \\
Fairview Flame & $44.8 \mathrm{~d}$ & $42.1 \mathrm{de}$ & $44.4 \mathrm{~cd}$ & $46.1 \mathrm{~b}$ & $46.1 \mathrm{~b}$ & $45.5 \mathrm{~b}$ \\
Franksred & $49.8 \mathrm{~b}$ & $47.5 \mathrm{~b}$ & $52.0 \mathrm{a}$ & $50.3 \mathrm{a}$ & $-_{--^{x}}$ & $-_{--^{x}}$ \\
Karpick & $43.8 \mathrm{ef}$ & $41.3 \mathrm{e}$ & $45.9 \mathrm{bc}$ & $46.2 \mathrm{~b}$ & $43.7 \mathrm{c}$ & $42.0 \mathrm{c}$ \\
Morgan & $44.5 \mathrm{de}$ & $43.6 \mathrm{~cd}$ & $46.8 \mathrm{~b}$ & $43.0 \mathrm{~cd}$ & $--^{\mathrm{x}}$ & $--^{\mathrm{x}}$ \\
Northwood & $51.0 \mathrm{a}$ & $50.3 \mathrm{a}$ & $52.6 \mathrm{a}$ & $51.8 \mathrm{a}$ & $51.6 \mathrm{a}$ & $48.7 \mathrm{a}$ \\
October Glory & $41.3 \mathrm{~h}$ & $39.3 \mathrm{f}$ & $42.1 \mathrm{ef}$ & $42.0 \mathrm{de}$ & $41.7 \mathrm{~cd}$ & $41.3 \mathrm{~cd}$ \\
Redskin & $40.3 \mathrm{i}$ & $38.6 \mathrm{f}$ & $41.3 \mathrm{f}$ & $42.5 \mathrm{c}-\mathrm{e}$ & $41.3 \mathrm{~d}$ & $37.9 \mathrm{e}$ \\
Scarsen & $42.4 \mathrm{~g}$ & $43.1 \mathrm{~cd}$ & $43.4 \mathrm{de}$ & $44.0 \mathrm{c}$ & $41.9 \mathrm{~cd}$ & $39.8 \mathrm{c}-\mathrm{e}$ \\
Schlesingeri & $46.2 \mathrm{c}$ & $41.2 \mathrm{e}$ & $46.1 \mathrm{bc}$ & $47.9 \mathrm{~b}$ & $48.3 \mathrm{~b}$ & $47.7 \mathrm{ab}$ \\
Tilford & $43.2 \mathrm{fg}$ & $44.3 \mathrm{c}$ & $46.9 \mathrm{~b}$ & $46.1 \mathrm{~b}$ & $40.0 \mathrm{~d}$ & $38.7 \mathrm{de}$ \\
\hline
\end{tabular}

${ }^{2}$ Units for SPAD-502 chlorophyll meter are dimensionless values, not percentages.

'Mean separation within columns by Duncan's multiple range test, $P \leq 0.05$.

${ }^{x}$ Foliar disease and early defoliation, hence data deleted.

Table 3. Leaf chlorophyll (fresh-weight basis) as determined by chlorophyll (CHL) extraction and SPAD-502 chlorophyll meter for selected red maple cultivars. ${ }^{2}$

\begin{tabular}{llc}
\hline \hline Cultivar & $\begin{array}{c}\text { Total CHL } \\
\text { extracted } \\
\left({\mathrm{mg} \cdot \mathrm{g}^{-1}}^{-1}\right)\end{array}$ & $\begin{array}{c}\text { SPAD-502 } \\
\text { meter values }^{\mathrm{y}}\end{array}$ \\
\hline Autumn Blaze & $4.18 \mathrm{~cd}^{\mathrm{x}}$ & $39.28 \mathrm{~d}$ \\
Autumn Flame & $5.09 \mathrm{a}-\mathrm{c}$ & $43.20 \mathrm{bc}$ \\
Fairview Flame & $5.38 \mathrm{a}$ & $42.85 \mathrm{bc}$ \\
Franksred & $5.20 \mathrm{ab}$ & $49.85 \mathrm{a}$ \\
Karpick & $4.82 \mathrm{a}-\mathrm{d}$ & $43.93 \mathrm{~b}$ \\
Morgan & $5.05 \mathrm{a}-\mathrm{c}$ & $47.28 \mathrm{a}$ \\
Northwood & $4.84 \mathrm{a}-\mathrm{d}$ & $49.85 \mathrm{a}$ \\
October Glory & $3.94 \mathrm{~d}$ & $37.85 \mathrm{~d}$ \\
Redskin & $4.07 \mathrm{~d}$ & $40.48 \mathrm{~cd}$ \\
Scarsen & $4.69 \mathrm{a}-\mathrm{d}$ & $44.60 \mathrm{~b}$ \\
Schlesingeri & $4.67 \mathrm{a}-\mathrm{d}$ & $44.35 \mathrm{~b}$ \\
Tilford & $4.30 \mathrm{~b}-\mathrm{d}$ & $47.38 \mathrm{a}$ \\
\hline
\end{tabular}

${ }^{2}$ Determinations made in June 1993.

'SPAD-502 chlorophyll meter units are dimensionless values, not percentages.

${ }^{x}$ Mean separation within columns by Duncan's multiple range test, $P \leq 0.05$.

tracted CHL and SPAD values across cultivars $(r=0.45 ; P \leq 0.001)$, with cultivars generally holding the same or similar rank by each method (Table 3), which is in agreement with results on other horticultural crops (Himelrick et al., 1992; Marquard and Tipton, 1987; Wood et al., 1993).

Foliar N concentrations by LECO-600CHN analysis in 1993 were lowest for 'Redskin' (Table4), with 'Karpick', 'Morgan', 'Tilford',
Table 4. Foliage characteristics of select red maple cultivars and a seedling group. ${ }^{2}$

\begin{tabular}{llc}
\hline $\begin{array}{l}\text { Cultivar/ } \\
\text { seedling }\end{array}$ & $\begin{array}{c}\text { Foliar N } \\
(\%)^{\mathrm{y}}\end{array}$ & $\begin{array}{c}\text { Leaf } \\
\text { chlorophyll }\end{array}$ \\
\hline Autumn Blaze & $2.3 \mathrm{c}-\mathrm{f}^{\mathrm{x}}$ & $42.5 \mathrm{~d}$ \\
Autumn Flame & $2.6 \mathrm{a}$ & $46.2 \mathrm{~b}$ \\
Fairview Flame & $2.4 \mathrm{a}-\mathrm{d}$ & $45.8 \mathrm{~b}$ \\
Franksred & $2.2 \mathrm{~d}-\mathrm{f}$ & $52.0 \mathrm{a}$ \\
Karpick & $2.1 \mathrm{ef}$ & $45.3 \mathrm{bc}$ \\
Morgan & $2.2 \mathrm{ef}$ & $42.9 \mathrm{~cd}$ \\
Northwood & $2.4 \mathrm{a}-\mathrm{e}$ & $51.1 \mathrm{a}$ \\
October Glory & $2.5 \mathrm{ab}$ & $43.2 \mathrm{~cd}$ \\
Redskin & $2.0 \mathrm{e}$ & $41.8 \mathrm{~d}$ \\
Scarsen & $2.5 \mathrm{a}-\mathrm{c}$ & $43.1 \mathrm{~cd}$ \\
Schlesingeri & $2.3 \mathrm{~b}-\mathrm{e}$ & $49.6 \mathrm{a}$ \\
Tilford & $2.2 \mathrm{~d}-\mathrm{f}$ & $42.9 \mathrm{~cd}$ \\
\hline
\end{tabular}

${ }^{2}$ Means per column represent 7200 samples each.

${ }^{y}$ Nitrogen levels by LECO CHN-600 analyzer and SPAD-502 chlorophyll values determined in Aug. and Sept. 1993.

'Mean separation within columns by Duncan's multiple range test, $P \leq 0.05$.

'Franksred', and 'Autumn Blaze' showing similar levels of foliar $\mathrm{N}$. The highest $\mathrm{N}$ levels occurred in 'Autumn Flame', while 'October Glory', 'Scarsen', 'Fairview Flame', and 'Northwood' showed similar levels (Table 4). Chlorophyll content, leaf greenness, or both are often considered to be closely related to foliar $\mathrm{N}$ levels. However, in this study 'Franksred', generally accepted among growers as having the deepest green pigmentation 
of the red maple cultivars, had one of the lowest concentrations of $\mathrm{N}$ while having one of the highest SPAD-502 values (Table 4). 'Redskin' had the lowest SPAD value, but was similar to other cultivars known for their lightgreen foliage. There was no correlation between SPAD-502 values and total foliar $\mathrm{N}$ concentrations $(r=0.15 ; P \leq 0.38)$.

Our results indicate that, for red maple cultivars grown under similar environmental conditions, the SPAD-502 is a reliable tool for ranking differences in leaf chlorophyll content in a consistent manner. Using a SPAD-502 meter may aid the originator of new or developing cultivars in determining relative leaf chlorophyll content objectively. In cultivars that have recognized standard selections, comparisons may be drawn to quantify differences in the response of cultivars to nutritional and environmental conditions.

Results for the evaluations we conducted did not separate the Freeman maples as a group from the A. rubrum cultivars. Values obtained for SPAD-502 season averages, N levels, and CHL content were interspersed among the $A$. rubrum cultivars.

Although a useful device for determinations of leaf chlorophyll content, the results of this study did not find the SPAD-502 meter to be a suitable substitute for foliar $\mathrm{N}$ analyses. As pointed out by Johnson (1993), because of the perennial nature of woody plants, they are usually more tolerant of nutritional variations than agronomic crops where SPAD chlorophyll meters have had some use as a diagnostic device for nutritional deficiencies. A massive cataloging of high and low leaf chlorophyll values for horticulture species with several cultivars is a work with significant potential.

\section{Literature Cited}

Bachtell, K.R. 1988. Acer $\times$ freemanii -A source for new shade tree selections. Proc. Intl. Plant Prop. Soc. 38:509-514.

Baker, W.H. and T.L. Thompson. 1992. Determination of total nitrogen in plant samples by Kjeldahl. Southern Coop. Serv. Bul. 368, p. 13-16.

Dirr, M.A. 1990. Manual of woody landscape plants: Their identification, ornamental characteristics, culture, propagation and uses. 4th ed. Stipes Publishing Co., Champaign, Ill. p. 64-68.

Fanizza, G., L. Ricciardi, and C. Bagnulo. 1991. Leaf greenness measurements to evaluate water stressed genotypes in Vitis vinifera. Euphytica 55:27-31.

Fare, D.C., C.H. Gilliam, H.G. Ponder, and W.A. Griffey. 1989. Acer rubrum cultivars for the south. Res. Ornamentals Rpt. 6:15, 17-18.

Himelrick, D.G., W.A. Dozier, Jr., C.W. Wood, and R.R. Sharpe. 1993. Determination of strawberry nitrogen status with SPAD chlorophyll meter. Adv. Strawberry Res. 12:49-53.

Himelrick, D.G., C.W. Wood, and W.A. Dozier, Jr. 1992. Relationship between SPAD-502 meter values and extractable chlorophyll in strawberry. Adv. Strawberry Res. 11:59-61.

Inskeep, W.P. and P.R. Bloom. 1985. Extinction coefficients of chlorophyll $a$ and $b$ in $N, N$ dimethylformamide and $80 \%$ acetone. Plant Physiol. 77:483-485.

Johnson, J.R. 1993. Evaluation of a chlorophyll meter to indicate relative growth rates of similar plant material. Proc. Intl. Plant Prop. Soc. 43:497-502.

Kaakeh, W., D.G. Pfeiffer, and R.P. Marini. 1992. Combined effects of spirea aphid (Homoptera: Aphididae) and nitrogen fertilization on net photosynthesis, total chlorophyll content, and greenness of apple leaves. J. Econ. Entomol. 85:939-946.

Kielbaso, J.J. 1990. Trends and issues in city forests. J. Arboricult. 16:69-76.

Krahl, K.H., M.A.Dirr, T.M. Halward, G.D. Kochert, and W.M. Randle. 1993. Use of single-primer
DNA amplifications for the identification of red maple (Acer rubrum L.) cultivars. J. Environ. Hort. 11:89-92.

Marquard, R.D. and J.L. Tipton. 1987. Relationship between extractable chlorophyll and an in situ method to estimate leaf greenness. HortScience 22:1327.

Monje, O.A. and B. Bugbee. 1992. Inherent limitations of nondestructive chlorophyll meters: A comparison of two types of meters. HortScience 27:69-71.

Santamour, F.S., Jr., and A.J. McArdle. 1982.Checklist of cultivated maples I. Acer rubrum L. J. Arboricult. 8:110-112.

Savé, R., J. Peñuelas, I. Filella, and C. Olivella. 1995. Water relations, hormonal level, and spectral reflectance of Gerbera jamesonii Bolus subjected to chilling stress. J. Amer. Soc. Hort. Sci. 120:515-519.

Tenga, A.Z., B.A. Marie, and D.P. Ormrod. 1989. Leaf greenness meter to assess ozone injury to tomato leaves. HortScience 24:514.

Tobolski, J.J. and R.D. Kemery. 1992. Identification of red maple cultivars by isozyme analysis. HortScience 27:169-171.

Turner, F.T. and M.F. Jund. 1991. Chlorophyll meter to predict nitrogen topdress requirement for semidwarf rice. Agron. J. 83:926-928.

van Gelderen, D.M., P.C. de Jong, and H.J. Oterdoom. 1994. Maples of the world. Timber Press, Portland, Ore.

Williams, J.D., D.C. Fare, C.H. Gilliam, G.J. Keever, H.G. Ponder, and J.T. Owen. 1993. Shade trees for the southeastern United States. Alabama Agr. Expt. Sta.

Wood, C.W., D.W. Reeves, and D.G. Himelrick. 1993. Relationships between chlorophyll meter readings and leaf chlorophyll concentration, $\mathrm{N}$ status, and crop yield: A review. Proc. Agron. Soc. N.Z. 23:1-9.

Yadava, U.L. 1986. A rapid and nondestructive method to determine chlorophyll in intact leaves. HortScience 21:1449-1450. 